\title{
PENGGUNAAN MODEL-MODEL PEMBELAJARAN JIGSA $W$ SECARA SIMULTAN DALAM UPAYA PENINGKATAN DAYA TARIK BELAJAR SISWA PADA MATA PELAJARAN PENDIDIKAN AGAMA KRISTEN KELAS VI SD NEGERI 068008 MEDAN TUNTUNGAN
}

\author{
Heri Silitonga* \\ Surel: herisilitonga@gmail.com
}

\begin{abstract}
From the frequency of data acquisition, it can be concluded that the average level of student activity is less active. It can be seen from the average percentage of student activeness of $15 \%$, which is in the less active category. The use of Jigsaw I can increase student learning data in Christian Education subjects in Class VI SD Negeri 068008 Kec Medan Tuntungan. The use of Jigsaw II further increases students' learning attractiveness in the subject of Christian Education in Class VI SD Negeri 068008 Kec Medan Tuntungan. Keywords: Increased, Attractiveness
\end{abstract}

\begin{abstract}
ABSTRAK
Dari frekuensi perolehan data tersebut, dapat disimpulkan bahwa ratarata tingkat keaktifan siswa adalah kurang aktif. Hal itu dapat dilihat dari rata-rata persentase perolehan keaktifan siswa sebesar 15\%, yaitu berada pada kategori kurang aktif. Penggunaan Jigsaw I dapat meningkatkan data tarik belajar siswa dalam mata pelajaran Pendidikan Agama Kristen di Kelas VI SD Negeri 068008 Kec. Medan Tuntungan. Penggunaan Jigsaw II lebih meningkatkan daya tarik belajar siswa dalam mata pelajaran Pendidikan Agama Kristen di Kelas VI SD Negeri 068008 Kec Medan Tuntungan.
\end{abstract}

Kata Kunci : Peningkatan, Daya Tarik

\section{PENDAHULUAN}

Pendidikan Agama memiliki peran yang amat penting dalam kehidupan umat manusia. Pendidikan agama mampu membentuk peserta didik menjadi manusia yang beriman dan bertaqwa kepada Tuhan Yang Maha Esa dan berakhlak mulia serta peningkatan potensi spiritual. Akhlak mulia mencakup etika, budi pekerti, dan moral sebagai perwujutan dari penididikan agama. Peningkatan potensi spiritual mencakup pengenalan, pemahaman, dan penanaman nilai-nilai keagamaan dalam kehidupan individual.

Selama ini pada proses pembelajaran sehari-hari guru mengajar pelajaran agama kepada siswa kurang kreatif, kurang variatif dan kurang memperhatikan kemampuan yang berbeda-beda yang 
dimiliki siswa. Kebanyakan guru dari mulai menyampaikan materi pelajaran sampai berakhirnya pelajaran hanya berceramah saja sehingga proses pembelajaran kurang menarik dan terasa monoton. Proses belajar mengajar di sekolah dasar, guru harus memiliki strategi-strategi agar siswa dapat belajar dengan efektif, efisien dan mengena pada tujuan pembelajaran.

Kurangnya daya tarik belajar siswa serta masih adanya beberapa siswa yang kurang fokus dalam mengikuti pelajaran agama masih dijumpai di Kelas VI SD Negeri 068008 Kec Medan Tuntungan. Hal ini terjadi karena kurangnya kreatif guru dalam mengajar dan minimnya metode yang digunakan sehingga membuat siswa belajar agama hanya sebagai rutinitas yang diharuskan untuk dipelajari oleh seluruh siswa yang beragama Kristen.

Berdasarkan survei yang saya lihat, daya tarik belajar siswa dalam mengikuti pelajaran Pendidikan Agama Kristen sangat rendah. Siswa Kelas VI SD Negeri 068008 Kec Medan Tuntungan kurang merespon, kurang berminat pelajaran yang disampaikan oleh guru agama. Karena guru agama masih menggunakan model pembelajaran ceramah yang membuat siswa bosan dan jenuh dalam mengikuti pelajaran Pendidikan Agama Kristen.

Tujuan pembelajaran dikatakan berhasil apabila siswa telah memiliki kemampuan untuk menguasai materi yang telah ditetapkan dalam kurikulum. Tujuan pembelajaran dilakukan agar pembelajaran dapat tercapai dengan efektif, untuk mencapai tujuan pembelajaran, maka harus menerapkan model pembelajaran yang sesuai dengan rencana pembelajaran. Hal ini didukung oleh pernyataan Trianto: "Model pembelajaran adalah suatu perencanaan atau suatu pola yang digunakan sebagai pedoman dalam merencanakan pembelajaran di kelas atau pembelajaran dalam tutorial".

Model pembelajaran mengacu pada pendekatan pembelajaran yang akan digunakan, termasuk di dalamnya tujuan-tujuan pengajaran, tahap-tahap kegiatan, lingkungan pembelajaran, dan pengolaan kelas. Model pembelajaran dapat didefinisikan sebagai kerangka konseptual yang melukiskan prosedur sistematis dalam mengorganisasikan pengalaman belajar untuk mencapai tujuan belajar. Melalui model pembelajaran guru dapat membantu peserta didik mendapatkan informasi, ide-ide, keterampilan, cara berfikir, dan mengekspresikan ide. Model pembelajaran dapat berfungsi sebagai pedoman bagi para perancang pembelajaran dan para guru dalam merencanakan aktifitas belajar mengajar.

Dari pengamatan di sekolah di kelas ternyata begitu banyak permasalahan yang ditemui, adapun 
Identifikasi masalah dalam penelitian ini adalah sebagai berikut:

1. Guru agama Kristen dalam mengajar pelajaran Pendidikan Agama Kristen masih monoton.

2. Siswa kurang respon terhadap pelajaran yang diberikan guru dan jenuh serta bosan saat mengikuti pelajaran Pendidikan Agama Kristen.

3. Model pembelajaran yang digunakan oleh guru agama Kristen belum dapat memicu siswa untuk lebih aktif dan kreatif.

4. Kurangnya daya tarik belajar siswa dalam mengikuti pelajaran Pendidikan Agama Kristen.

5. Model-model pembelajaran Jigsaw

I, II, dan III secara simultan belum digunakan oleh guru agama Kristen

6. Model pembelajaran Jigsaw belum dilakukan secara efektif dilakukan dalam meningkatkan daya tarik siswa terhadap mata pelajaran Pendidikan Agama Kristen sebagai hasil prestasi belajar siswa.

Dalam melakukan penelitian tentunya memiliki manfaat, baik secara teoritis maupun secara praktis. Oleh karena itu, penulis mengiginkan agar melalui penelitian ini dapat bermanfaat bagi banyak pihak yaitu:

\section{Manfaat Teoritis}

a. Melalui penelitian ini diharapkan bermanfaat untuk memperluas wawasan dan wacana bagi guru agama Katolik tentang penggunaan model-model pembelajaran jigsaw secara simultan dalam upaya peningkatan daya tarik siswa pada mata pelajaran Pendidikan Agama Kristen di Kelas VI SD Negeri 068008 Kec. Medan Tuntungan.

b. Sebagai bahan perbandingan bagi penelitian selanjutnya dalam bidang penggunaan model-model pembelajaran jigsaw secara simultan dalam upaya peningkatan daya tarik siswa pada mata pelajaran Pendidikan Agama Kristen di SD Negeri 068008 Kec. Medan Tuntungan.

\section{METODE PENELITIAN}

Tempat penelitian ini dilaksanakan oleh peneliti di SD Negeri 068008 Kec. Medan Tuntungan. Adapun alasan penulis memilih sekolah ini sebagai tempat penelitian adalah untuk mengembangkan dan menciptakan pembelajaran yang efektif dan efisien di lingkungan sekolah dengan menggunakan model pembelajaran kooperatif tipe Jigsaw I, II, dan III.

Adapun waktu penelitian ini dilaksanakan selama dua bulan, yaitu bulan April sampai Mei 2016, kegiatan peneliti terdiri dari kegiatan izin penelitian, pengumpulan data, analisi data, penyusunan konsep laporan dan diakhiri penyampaian hasil laporan peneliti.

Penentuan populasi dan sampel dalam suatu penelitian yang dilaksanakan merupakan hal yang 
sangat penting bagi penulis, karena populasi dan sampel ini turut menentukan pelaksanaan penelitian yang ditinjau dari segi waktu, kemampuan, biaya dan tujuan penelitian itu sendiri.

Ada tiga sumber data penting yang dijadikan sebagai penggalian dan pengumpulan data serta informasi dalam penelitian ini. Sumber data tersebut meliputi:

1. Tempat dan peristiwa yang menjadi sumber data dalam penelitian ini, yaitu kegiatan dalam proses pembelajaran Pendidikan Agama Kristen yang berlangsung di dalam kelas dengan menggunakan model-model pembelajaran tipe jigsaw I, II, dan III secara simultan.

2. Informan dalam penelitian ini dengan menggunakan hasil evaluasi siswa dalam mengikuti pelajaran Pendidikan Agama Kristen.

3. Dokumen yang berupa rekaman aktivitas siswa dalam mengikuti pelajaran Pendidikan Agama Kristen.

\section{HASIL DAN PEMBAHAASAN} Lokasi penelitian pembelajaran adalah di Kelas VI SD Negeri 068008 Kec. Medan Tuntungan. Adapun waktu penelitian pembelajaran ini dilakukan pada semester II Mata pelajaran Pendidikan Agama Kristen dengan Metode Jigsaw secara simultan.

\section{Hasil Penelitian}

Hasil penelitian diuraikan dalam tahapan yang berupa siklus-siklus pembelajaran yang dilakukan sebagai berikut:

\section{Pertemuan I}

Hasil penelitian Pertemuan I menyajikan laporan hasil-hasil setiap tahapan penelitian tindakan kelas, mulai perencanan, pelaksanaan tindakan, observasi dan evaluasi, dan refleksi. Berdasarkan hasil tindakan I, faktor yang diduga menjadi penyebab timbulnya permasalahan tersebut adalah metode yang dipakai kurang bisa membantu siswa untuk menuangkan idenya karena siswa baru mengenal metode pembelajaran jigsaw $\mathrm{I}$.

Perencanaan

Penyusunan RPP (Rencana Perbaikan Pembelajaran) untuk observasi proses belajar mengajar yang bisa dilakukan guru, pada pelajaran Pendidikan Agama Kristen.

Kegiatan selanjutnya terdiri dari kegiatan merumuskan tujuan pembelajaran, menyusun langkahlangkah pembelajaran, merencanakan alat yang sesuai dengan pokok bahasan yang akan diajarkan.

Mempersiapkan daftar pengamatan sebagai acuan untuk mengumpulkan data tentang daya tarik belajar siswa dalam mengikuti pelajaran Pendidikan Agama Kristen serta menyiapkan bahan penelitian. 
Pelaksanaan

Saat pelaksanaan tindakan, peneliti bertindak sebagai guru melakukan pengamatan yang memantau jalannya proses pembelajaran. Guru melaksanakan pembelajaran dengan menggunakan Metode Jigsaw I untuk meningkatkan Daya tarik belajar dimana guru menggunakan media yang mendukung sesuai dengan materi yang disampaikan, guru kemudian memberikan pertanyaan-pertanyaan untuk dijawab bersama dalam kelompok. Dengan topik "Sikap Terhadap Orang Tua, Kehidupan diri Sendiiri dan Sesama"

Observasi

Pada waktu guru mengajar, peneliti melakukan pengumpulan data dengan cara mencatat kejadiankejadian selama kegiatan pembelajaran berlangsung untuk mengetahui sejauh mana Daya Tarik belajar siswa sebelum dan sesudah diberi tindakan. Untuk mengetahui perkembangan Daya Tarik belajar siswa. Untuk mengetahui peningkatan daya tarik belajar siswa dalam mengikuti pelajaran dengan topik "Sikap Terhadap Orang Tua, Kehidupan diri Sendiiri dan Sesama"
Untuk memudahkan peneliti dalam mengumpulkan data tentang peningkatan Daya tarik belajar siswa, maka peneliti membuat tabel pedoman penilaian peningkatan daya tarik belajar siswa, seperti berikut:

Keterangan:

Persentase

$=\frac{\text { Skor Perolehan } \times 100 \%}{\text { Skor Maksimal }}$

Kategori Penilaian Tingkat Keaktifan

$90 \%-100 \%$ Sangat Tinggi

$75 \%-89 \% \quad$ Tinggi

$55 \%-74 \% \quad$ Normal

$35 \%-54 \% \quad$ Rendah

$0 \%-34 \% \quad$ Sangat Rendah

Kegiatan pengamatan Pertemuan I ini dilakukan untuk mengetahui lebih bagaimana peningkatan Daya tarik belajar siswa selama proses belajar mengajar berlangsung dengan menggunakan metode Jigsaw I.

Persentase keaktifan siswa yang diperoleh seperti terdapat pada tabel di atas, kemudian dibandingkan dengan kategori penilaian tingkat keaktifan siswa yang telah ditentukan sebelumnya, sebagai berikut: 
Heri: Penggunaan Model-Model...

Tabel.2.1 Frekuensi Tingkat Keaktifan Siswa

Pertemuan I

\begin{tabular}{l|l|l|l}
\hline Kategori & Frekuensi & Persentase Frekuensi & Tingkat Keaktifan \\
\hline $90 \%-100 \%$ & 4 & $20 \%$ & Sangat Aktif \\
\hline $75 \%-89 \%$ & 6 & $30 \%$ & Aktif \\
\hline $55 \%-74 \%$ & 7 & $35 \%$ & Kurang Aktif \\
\hline $35 \%-54 \%$ & 3 & $15 \%$ & Tidak Aktif \\
\hline $0 \%-34 \%$ & 0 & $\%$ & Sangat Tidak Aktif \\
\hline
\end{tabular}

Tabel di atas menunjukkan bahwa siswa yang sangat aktif 4 orang (20\%), siswa yang aktif 6 orang (30\%), siswa yang kurang aktif 7 orang (35\%), siswa yang tidak aktif 3 orang $(15 \%)$ dan siswa yang sangat tidak aktif 0 orang $(0 \%)$.

Dari frekuensi perolehan data tersebut di atas, dapat disimpulkan bahwa rata-rata tingkat keaktifan siswa adalah kurang aktif. Hal itu dapat dilihat dari rata-rata persentase perolehan keaktifan siswa sebesar $35 \%$, yaitu masih berada pada kategori kurang aktif.

\section{Grafik 3.1}

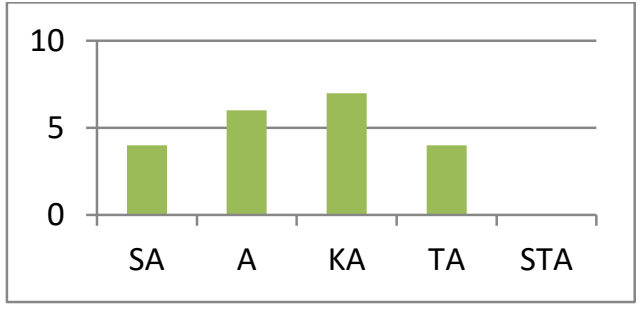

1).Siswa mulai mampu mengungkapkan pendapatnya lewat tanya jawab. 2).Siswa mulai bertukar pikiran dengan temannya. 3). Keberanian siswa untuk mengeluarkan ide dan gagasannya baik pada waktu tanya jawab berlangsung masih biasa. 4). Dorongan dan bimbingan kepada siswa perlu ditingkatkan karena masih ada siswa yang kurang semangat dalam mengikuti pelajaran. 5).Siswa kurang termotifasi untuk belajar Pendidikan Agama Kristen

1.Pertemuan II

a. Perencanaan

Pertemuan II ini merupakan, perencanaan dalam pertemuan ini dituangkan dalam bentuk Silabus dan Rencana Pelaksanaan Pembelajaran (RPP) yang dibuat dengan merujuk kepada Metode Jigsaw II. Menetapkan Sumber belajar merujuk pada hasil pengamatan siswa di lapangan dan buku paket mata pelajaran serta. Penilaian tingkat keaktifan siswa yang telah ditentukan sebelumnya, sebagai berikut 
Tabel. 2.2 Frekuensi Tingkat Keaktifan Siswa Siklus II

\begin{tabular}{llll}
\hline Kategori & Frekuensi & $\begin{array}{l}\text { Persentase } \\
\text { Frekuensi }\end{array}$ & Tingkat Keaktifan \\
\hline $90 \%-100 \%$ & 5 & $25 \%$ & Sangat Aktif \\
\hline $75 \%-89 \%$ & 11 & $55 \%$ & Aktif \\
\hline $55 \%-74 \%$ & 4 & $20 \%$ & Kurang Aktif \\
\hline $35 \%-54 \%$ & 0 & $0 \%$ & Tidak Aktif \\
\hline $0 \%-34 \%$ & 0 & $0 \%$ & Sangat Tidak Aktif \\
\hline
\end{tabular}

Dari tabel di atas, dapat diketahui bahwa tingkat Daya tarik belajar siswa berada pada kategori aktif. Hal itu dapat dilihat dari persentase tingkat keaktifan siswa yang sangat aktif dan aktif masingmasing adalah $25 \%$ dan $55 \%$. Hal ini berarti bahwa telah terjadi peningkatan yang positif dan signifikan dari keaktifan belajar siswa dari pertemuan sebelumnya, dimana tingkat keaktifan belajar siswa pada peretemuan I berada kategori kurang aktif.

$$
\text { Untuk mengetahui }
$$

peningkatan daya tarik belajar siswa dalam mengikuti pelajaran dengan topik "Sikap Terhadap Orang Tua, Kehidupan diri Sendiiri dan Sesama" yang dilakukan dengan menerapkan metode permbelajaran Jigsaw III, maka digunakan tabel observasi seperti berikut:

$$
\text { Kegiatan pengamatan }
$$
pertemuan III, dilakukan untuk mengetahui peningkatan daya tarik belajar siswa dalam proses belajar mengajar berlangsung dengan menggunakan metode Jigsaw III. Penilaian tingkat keaktifan siswa yang telah ditentukan sebelumnya, sebagai berikut: 
Heri: Penggunaan Model-Model...

Tabel. 2.3 Frekuensi Tingkat Keaktifan Siswa

\section{Pertemuan III}

\begin{tabular}{l|l|l|l}
\hline Kategori & Frekuensi & $\begin{array}{l}\text { Persentase } \\
\text { Frekuensi }\end{array}$ & Tingkat Keaktifan \\
\hline $90 \%-100 \%$ & 2 & $10 \%$ & Sangat Aktif \\
\hline $75 \%-89 \%$ & 5 & $25 \%$ & Aktif \\
\hline $55 \%-74 \%$ & 5 & $25 \%$ & Kurang Aktif \\
\hline $35 \%-54 \%$ & 5 & $25 \%$ & Tidak Aktif \\
\hline $0 \%-34 \%$ & 3 & $15 \%$ & Sangat Tidak Aktif \\
\hline
\end{tabular}

Tabel di atas menunjukkan bahwa siswa yang sangat aktif 2 orang (10\%), siswa yang aktif 5 orang (25\%), siswa yang kurang aktif 5 orang $(25 \%)$, siswa yang tidak aktif 5 orang $(25 \%)$ dan siswa yang sangat tidak aktif 3 orang (15\%).

Perolehan Tingkat Keaktifan Siswa meningkatkan daya tarik belajar siswa.

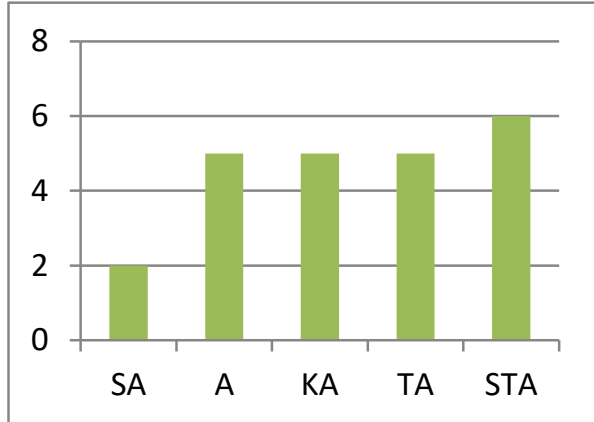

\section{SIMPULAN}

Berdasarkan analisis data dan hasil penelitian tindakan kelas (classroom Action research) yang dilakukan dapat disimpulkan bahwa:
Dari frekuensi perolehan data tersebut di atas, dapat disimpulkan bahwa rata-rata tingkat keaktifan siswa adalah kurang aktif. Hal itu dapat dilihat dari rata-rata persentase perolehan keaktifan siswa sebesar $15 \%$, yaitu berada pada kategori kurang aktif.

Penggunaan model pembelajaran Jigsaw I dapat meningkatkan daya tarik belajar siswa Kelas VI SD Negeri 068008 Kec Medan Tuntungan Medan Polonia. Terlihat dari tabel observasi yang sudah di lakukan dimana menunjukkan bahwa siswa yang sangat aktif 4 orang (20\%), siswa yang aktif 6 orang (30\%), siswa yang kurang aktif 7 orang (35\%), siswa yang tidak aktif 3 orang (15\%) dan siswa yang sangat tidak aktif 0 orang $(0 \%)$.

$$
\text { Penggunaan model }
$$

Pembelajaran Jigsaw II dapat meningkatkan daya tarik belajar siswa Kelas VI SD Negeri 068008 
Kec. Medan Tuntungan bahkan lebih meningkat dibandingkan dengan Jigsaw I, dapat diketahui bahwa tingkat daya tarik belajar siswa berada pada kategori aktif. Hal itu dapat dilihat dari persentase tingkat keaktifan siswa yang sangat aktif dan aktif masing-masing adalah $25 \%$ dan $55 \%$. Hal ini berarti bahwa telah terjadi peningkatan yang positif dan signifikan dari keaktifan belajar siswa dari pertemuan sebelumnya, dimana tingkat keaktifan belajar siswa pada peretemuan I berada kategori kurang aktif. Dan dalam penggunaan Jigsaw II lebih mampu menarik belajar siswa karena dalam Jigsaw II ada pemberian hadiah bagi kelompok unggulan.

\section{Penggunaan}

model

Pembelajaran Jigsaw III kurang meningkat di bandingkan dengan Jigsaw I, dan II menunjukkan bahwa siswa yang sangat aktif 2 orang $(10 \%)$, siswa yang aktif 5 orang (25\%), siswa yang kurang aktif 5 orang (25\%), siswa yang tidak aktif 5 orang $(25 \%)$ dan siswa yang sangat tidak aktif 3 orang (15\%). Dari frekuensi perolehan data tersebut, dapat disimpulkan bahwa rata-rata tingkat keaktifan siswa adalah kurang aktif. Hal itu dapat dilihat dari rata-rata persentase perolehan keaktifan siswa sebesar $15 \%$, yaitu berada pada kategori kurang aktif.

Penggunaan model-model pembelajaran Jigsaw tidak dilakukan secara bersamaan terlihat dari hasil observasi diatas bahwa yang berhasil di gunakan hanya Jigsaw I dan
Jigsaw II sedangkankan Jigsaw III tidak dapat meningkatkan daya tarik belajar siswa karena setelah dilakukan penerapan jigsaw III siswa kurang mengerti karna selama proses pembelajaran berlangsung menggunakan bahasa Inggris. Sedangkan tidak semua siswa mengerti berbahasa inggris.

Dalam proses belajar mengajar, guru hendaknya mampu menciptakan suasana belajar yang mampu membuat siswa aktif dan menyenangkan sehingga siswa memiliki daya tarik belajar.

Setelah melakukan penelitian penggunaan Jigsaw I, II, dan II penulis lebih menyarankan agar guru lebih menggunakan Jigsaw I dan II karna lebih dapat menarik minat belajar siswa dalam mengikuti proses belajar mengajar.

Setelah melakukan penelitian penulis berharap para guru Agama dapat lebih variasi dalam menggunakan metode belajar didalam kelas.

Metode Jigsaw sebaiknya digunakan dalam pelajaran agama karena memacu siswa lebih kreatif dan aktif di dalam kelas, serta mampu mendorong siswa lebih giat lagi dalam belajar.

\section{DAFTAR RUJUKAN}

Alkitab. Jakarta: Lembaga Alkitab Indonesia. 2013 
Heri: Penggunaan Model-Model...

Arikunto Suharsimi. Prosedur Suatu

Pendekatan Praktis. Jakarta:

Bina Aksara, 2005.

Dimyanti \& Mudjiono. Belajar Dan

Pembelajaran. Jakarta:

Rineka Cipta 2002

Dunne R, \& Ted W. Pembelajaran Efektif, terjemahan Anwar Jasin. Jakarta: Penerbit PT Gramedia Widiasarana Indonesia, 1996.

Dimyati dan Mudjiono, Belajar dan Pembelajaran, Jakarta: Rineka Cipta, 2009.

Gultom, Ramli. 2010. Menjadi Penulis Penelitian Tindakan di kelas dan di sekolah, Medan:USU Perss.

Hariyanto. Perbandingan Hasil Belajar Matematika Antara Siswa Yang Pembelajarannya Menggunakan Model Kooperatif Tipe Jigsaw Dengan Model Tradisional Di Kelas II Man Jember. Tesis Bandung: PPS UPI 2000.

Isjoni. cooperative learning. Bandung; Alfabeta, 2013.

Cooperative Learning

Mengembangkan

Kemampuan Berkelompok. Bandung: Alfabeta 2007.

Lie, Anita. Coopearative Learning. Jakarta : Grasindo 2008.
M Abdurrahman dan B Totok. Memahami dan Menangani Siswa dengan Problema dalam Relajar: Pedoman Guru. Jakarta: Proyek Peningkatan Mutu SLTP Direktorat Pendidikan Menengah Umum, Direktorat Pendidikan Dasar dan Menengah; Departemen PendidikanNasional, 2000.

Mukhtar H. Bimbingan Skripsi,Tesis, dan Artikel Ilmiah: Panduan Berbasis Kualitatif Lapangan Dan Perpustakaan. Jakarta: Gaung Persada Press, 2007.

Muslich, Masnur, Melaksanakan PTK Itu mudah: pedoman praktis bagi guru professional, Jakarta: Bumi Aksara, 2009.

Nuhamara, Daniel, Pembimbing Pendidikan Agama Kristen,

Jakarta:Dirjen Bimas Kristen Protestan dan Universitas Terbuka, 1992.

Pembimbing PAK, Bandung ; Jurnal Info Media, 2007.

Nainggolan. JM., Strategi Pendidikan Agama Kristen, Jakarta: Generasi Info Media, 2008. 